\title{
The Psychological Potential of Water Surfaces in Urban Design: A Study of Urban Environments in Prague and Santa Cruz de Tenerife
}

\author{
Lucie Havránková ${ }^{1 *}$, Pavel Ondr ${ }^{1}$, Jana Moravcová ${ }^{1}$ and Jiří Sláma ${ }^{1}$
}

1 Department of Landscape Management, Faculty of Agriculture, University of South Bohemia in České Budějovice; Na Zlaté stoce 3, 37005 České Budějovice, Czech Republic; ondr@zf.jcu.cz (P.O.); moravj04@zf.jcu.cz (J.M.); slamaj@zf.jcu.cz (J.S.)

* Correspondence: havral01@zf.jcu.cz; Tel.: +420776563440

\begin{abstract}
This article focuses on the comparison and perception of the potential of water's sur-face in selected parts of the waterfront in two contrasting cities. The aim is to define the potential of the water's surface in terms of psychology and its effects on climate. The analysis was performed on the example of Prague with its waterfront on the river Vltava, and Santa Cruz de Tenerife with its Atlantic coastline. Data was sourced from maps, questionnaire surveys and interviews with waterfront users during October 2020. The research showed a higher importance of the water's surface for users in Prague, than in Santa Cruz. The main finding is that the psychological perception of the waterfront by its the users is affected by the possibility of a visual contact with the water's surface, the design and composition of the space, and the climate situation of a site affected by the presence of an urban heat island (UHI). The results promote an adherence to ecosystem-based approaches in future design projects and modifications of existing public spaces. The purpose of the work is to open a broader debate on the sustainability of the potential of waterfronts and their positive impact on human health.
\end{abstract}

Keywords: waterfront; ecopsychology; urbanism; Prague; Santa Cruz de Tenerife

\section{Introduction}

Water is a vitally important substance that distinguishes the Earth from the other planets of the Solar System [1]. In its liquid and frozen state, water covers 75\% of Earth's surface. The total volume of water on Earth is 1.39 billion cubic kilometers [2]. A key role in this study is played by water as part of the urban and architectural composition. Waterfronts, from the perspective of the psychology of perception, are a unique element in the city's natural landscape. The aim is to identify the potential of these valuable urban elements as users perceive them.

\subsection{The importance of the water's surface}

According to Önen [3], the effects of water as an element in urban planning involve both aesthetic and functional effects. Aesthetic effects cover the general perception of the water's surface. This includes visual, sonic, tactile and psychological effects.

The primary force attracting the inhabitants of an urban environment to water is the visual effect of the water's surface. This effect mediates a sense of belonging between the water's surface and the sky and opens up a new dimension [4]. According to Herzog [5], the preference of water as a visible feature is referred to as hydrophilia. The study of Bulut and Yilmaz [6] on the visual assessment of the quality of aquatic environment showed that the most popular category of visual perception is urban aquatic scenery with [visual quality point $(\mathrm{VQP})=6.0391$ ] and scenery of waterfalls $(\mathrm{VQP}=5.88594)$, whereas the least preferred category is river scenery $(\mathrm{VQP}=3.5547)$.

The sound of water has a generally soothing effect [7], whether it is the rhythmic repetition of the sound of waves breaking on the shore, or the continuous bubbling of a stream. By the movement of water, sources of the sound of water are either static or dynamic. The sound of sea waves has an inspirational effect. Since the 1970s, its positive 
impact on the human psyche had stimulated the reproduction of the sound of waves for commercial use as "The Psychologically Ultimate Seashore" [4]. This and other similar recordings highlighted the romantic quality of the water's surface. The sound of this element had served as an inspiration and theme for many musical works since early history [8].

On the other hand, the character of tactile effects is personal. Description cannot replace the sensation we get from rain falling on our face, from the mist surrounding waterfalls, or from diving into the waters of a sea or lake. According to Hattapoğlu [9], diving into water is an escape of sorts from the physical world.

\subsection{The effect of the water element on human health and psyche}

Bachelard [10] assumed that aesthetic value of water lies in its naturalness. In compliance with psychological theory, naturalness enhances wellbeing and activates social and exploratory behaviour [11]. We know that psychology is the science studying human experience and behaviour [12]. It is experience that differs between individuals. If we want to understand someone's relationship to nature and the environment, we need to understand their individual needs for contact with nature, their aesthetic approach to nature and their environmental awareness [13]. There are two types of need for contact with nature: individuals with a higher need for contact with nature seek ways of spending as much time in the countryside as possible. They are fascinated by the world of nature and attracted to it. On the other hand, individuals with a lower need for contact with nature are indifferent to it. Differences in individuals' intensity of aesthetic experience from contact with nature are defined by their aesthetic approach to it [14]. Inner motivation towards the protection of the natural environment is manifested in individuals with a higher environmental awareness [15]. An individual with such an orientation is aware of the environmental context of life and seeks ways how to be more considerate of nature. The need for contact with nature cannot be summarised in a single definition [12].

In terms of psychology, the effects of the water's surface on individuals come under environmental psychology or ecopsychology. This discipline deals with the principles of understanding in oneself the impacts of the external environment. It sees human life as a conscious part of the planet's ecological community [16]. Although this discipline is relatively young, it is essential for the understanding of human thinking and behaviour, as well as for the description of all the other psychological processes, and also for the application of psychology in improving one's everyday life [17]. The research of M. D. Velarde et al. [18] analysed studies of individual rural and urban scenery, which, based on understanding the background with the strongest positive impacts, could improve the perception of the urban environment in terms of its potential. It is also worth mentioning the constructivist approach of landscape research. The multisensory impact of water on individual's psychology and emotions is essential [19].

We can say that water has a healing effect on psychological diagnoses, from the alleviation of anxiety to the amelioration of deeper mental disorders. These healing effects are mediated by the physical properties of the aquatic element as well as its symbolic representation [16]. Being amidst nature reduces stress [20] and cognitive fatigue. Contact with nature has beneficial effects on health, such as normalisation of blood pressure and heart rate [21]. There are two theories explaining this restorative effect of nature. Attention restoration theory (ART) by R. and S. Kaplan [11] notes the effect of the natural environment on our attention. Whereas everyday life exhausts cognitive attention through active concentration, nature allows for an unconscious shift of attention, which requires little or zero effort. According to the authors, this allows for relaxation of conscious attention and its restoration. On the other hand, the psycho-evolutionary theory of R. Ulrich [22] explains the restorative effect of contact with nature as due to stress reduction.

In terms of the psychology of architecture and design the important aspect is the proximity of the water's surface. Waterfronts in cities represent appealing places that attract attention. Design projects should reflect the fact that they are highly sensitive and 
complex spaces. The founder of ecopsychology, T. Roszak [23], summarised all this in his definition: "Psychology needs ecology and ecology needs psychology".

\subsection{Waterfronts}

Waterfronts, as "urban areas in direct contact with water" [24] play a primary role in this study. They are the points where two different environments meet - the landscape of the city and that of the river or another body of water. This sensitive relationship between the aquatic landscape and urban settlement culminates at the point where these two elements meet, i.e. the waterfront [25]. Waterfronts therefore act as boundaries between two different environments, and at the same time they act as elements framing the city within the surrounding landscape [26]. According to Wrenn [27] there are several types of urban location involving water, as listed below. The first two represent coastal cities, and the remaining three represent mainland cities [28]:

- $\quad$ A, Urban area on a peninsula.

- B, Urban area in a bay.

- $\quad$ C, Urban area on the bank of a river.

- $\quad$ D, Urban area on the bank of intersecting (confluence of) rivers.

- $\quad$ E, Urban area on the bank of large water bodies.

Following this classification, the study works with two of the most typical and at the same contrasting types of waterfront. Cities with a coastal waterfront and cities with a mainland waterfront. Research and comparison of these categories will offer a comprehensive view of the importance of the perceived aquatic environment.

It is necessary to design contemporary projects of waterfront revitalisation in a way that will also make them relevant in the future [29]. The term sustainable development has often been used in this context. Under sustainable development we understand "development that meets the needs of the present generations without compromising the ability of future generations to meet their own needs" [30].

Waterfronts are unsuitable for mono-functional uses [31]. The design of a waterfront needs to seek ways of implementing all the functions in a highly sensitive environment. The frequency of each of its functions, its continuity, and its harmony with the urban spaces create a fully operational waterfront where transport, industry and essential recreation coexist [25]. For mental wellbeing and health, both passive and active types of recreation near the water are desirable. Due to this, sports facilities allowing for active recreation are essential within waterfronts [32]. Besides facilities for sports and leisure, the waterfront space should also offer a dimension that accommodates culture [33]. Besides permanent facilities and equipment, attractions situated on the waterfront are becoming increasingly popular. These may include concert halls, museums, festivals and art exhibitions [34]. Places with a view of the water's surface thus gain new cultural dimensions [35]. Emotional contact with water happens when people are allowed to get as close to water as possible without physically touching the element. This results in "mental leaning out over" [36]. Waterfronts should be physically and visually accessible to all types of users [37].

\section{Materials and Methods}

The study analyses the potential approach of users to the waterfront in the continental Central European city of Prague, and in the island city of Santa Cruz de Tenerife. The objective is an assessment of the importance of the view of the water's surface in terms of psychology in the everyday life of the local inhabitants, and also an evaluation of the impact of air temperatures on the behaviour of users within the waterfront. The data will offer an opportunity to compare two contrasting locations, but also a comprehensive insight into users' preferences in each of the locations. The current degree of the perceived impact of the climate's effect on users of waterfront will be evaluated. The results will contribute to a deeper understanding of the psychological aspects in architectural and urban planning solutions for future waterfront designs. 
For the case study, a three-kilometre-long segment of waterfront in the city centre was selected. The analysis, which was preceded by the selection and specification of the cities and a comprehensive overview of their spatial development, consists of three parts. The data was sourced from maps and from own questionnaire surveys, accompanied by semi-structured interviews and targeted responses of the users. These quantitative survey questions were designed as objective questions aimed at obtaining detailed insights from different groups of respondents. The questionnaire was divided into two parts. In the first part, identification data and positively or negatively per-ceived segments of the Vltava river embankment were ascertained. The second part of the questionnaire survey examined the perceived areas of interest of specific sections. Respondents also mentioned perceived social and physical aspects. The results of the questionnaire were processed together with the results of semi-structured interviews. The research was carried out among 150 local users of the waterfront in each of the cities. Data collection took place in September and October 2020.

In the first phase, the selected model area was analysed, and the shortest distances of the pedestrian promenade from the water's surface was specified. The results are presented in attached maps. Upon a questionnaire survey, positively and negatively perceived parts of the waterfront were identified. Then, in the most positively and most negatively perceived segments, the strengths and weaknesses of economic, environmental and social aspects were identified and evaluated. The second phase focused on investigating the degree of perception of the individual social and physical aspects in three age categories in order to evaluate the importance of the water's surface for the users against the other social aspects. Physical aspects in terms of their impact on the user were evaluated as well. In the third phase, the sum of the users passing (passers-by) was calculated in the positively and negatively perceived segments of the waterfront. The passers-by were classified in terms of the purpose of their presence on the site. Air temperature was recorded at regular hourly intervals to evaluate the effect of the waterfront on the climate.

\section{Results}

\subsection{Study area}

\subsubsection{Prague}

The selected segment runs along the right bank of the River Vltava, in the north-west direction (Figure 1). The three-kilometre-long segment is connected with the left bank via five bridges and passes through four embankment zones. The starting point is the Vyšehrad tunnel, beyond which starts the Rašínovo nábřeží. There the pedestrian promenade runs along the river, in the close vicinity of the water. The waterfront then continues under the Vyšehrad railway bridge and Palacký Bridge. This section belongs to the most social and lively space with access for party boats, a theatre boat and farmers markets held on the embankment during the weekends [38]. Approximately $10 \mathrm{~m}$ above the level of the embankment runs the busy street with a tram line. The pedestrian promenade gradually rises to this level along the Masarykovo nábřeží, which leads along the Slovanský ostrov island with the landmarks of the Mánes Gallery and Žofín Palace, built in the New Renaissance style in 1885 [39]. Masarykovo nábřeží ends with the National Theatre and the Legion Bridge. Here it links to Smetanovo nábřeží, which runs along the traffic route to Křižovnické náměstí square, where the pedestrian route turns left to Platnéřská street and back to the waterfront - Alšovo nábřeží. The studied area ends at the Mánes Bridge. 

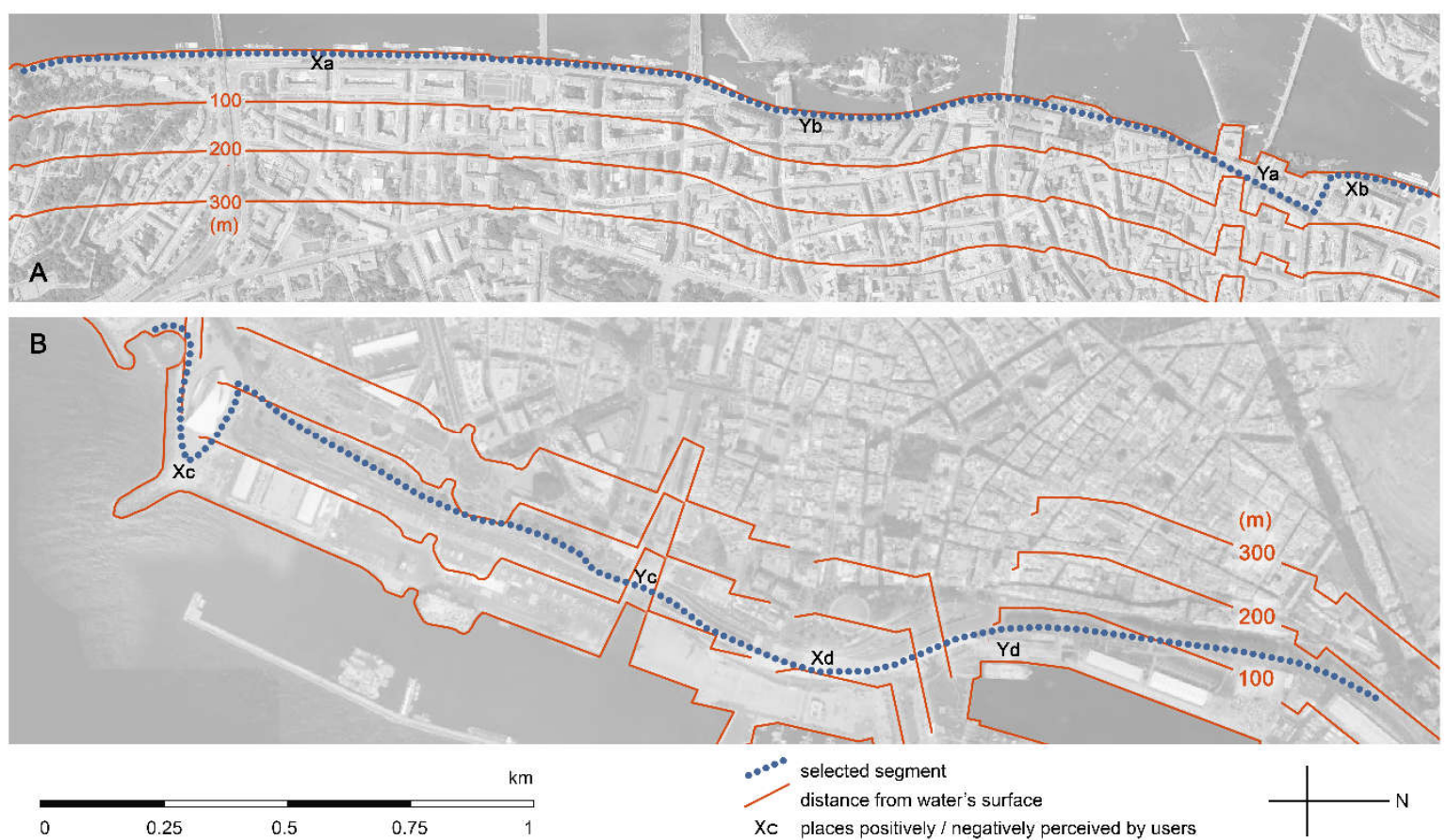

Figure 1. Analysed segment showing distances from water's surface and positively / negatively perceived places as evaluated by the users in Prague (a) and Santa Cruz de Tenerife (b); ArcGIS

\subsubsection{Santa Cruz de Tenerife}

The studied pedestrian segment runs along the waterfront part of the city centre. The starting point is the Castle of St. John the Baptist [40]. From there a pedestrian path leads to the Auditorio de Tenerife with a panoramic view of the ocean [41].

Another segment is the promenade along Avenida de la Constitución, which represents the city's principal highway. This segment is separated from the ocean by logistical facilities and continues in a similarly designed way along Avenida Marítima, where sports facilities are situated around a roundabout. Then there is the Plaza de España with its large reflecting pool and a fountain. This wide space serves the public on two levels, one upon the other: the lower level for heavy traffic and the upper level for connecting the city's pedestrian zone with the new port and the ocean. The visual design of the square is inspired by lava flow or a large beach. The place is capable of accommodating major public festivals, such as the Carnaval [42]. For the purposes of this study, the selected section of the pedestrian path ends by the point where the Avenida intersects the street Rambla de Santa Cruz.

\subsection{Analysis}

The distances of the shorter promenades in both cities are indicated in the schematic maps (Figure 1). A smaller distance separates the users from the water's surface in Prague, where in $89 \%$ of the studied segment of the waterfront the maximum distance is $50 \mathrm{~m}$. Compared to Prague, the pedestrian waterfront in Santa Cruz de Tenerife comes into close contact with the waterfront in just $11.5 \%$ of the selected segment. The reasons for this are numerous obstacles, such as the logistical facilities and the port structures.

Table 1. Evaluation of positively and negatively perceived places in Prague and Santa Cruz

\begin{tabular}{|c|c|c|c|c|c|c|c|}
\hline \multicolumn{4}{|c|}{ POSITIVELY perceived segment of Prague } & \multicolumn{4}{|c|}{ NEGATIVELY perceived segment of Prague } \\
\hline mark on map & segment & no. of resp. & $\%$ & mark on map & segment & no. of resp. & $\%$ \\
\hline Xa & Rašínovo nábřeží & 86 & 57,33 & Ya & around Kř́ížov. náměstí & 93 & 62 \\
\hline \multirow[t]{2}{*}{$\mathbf{X b}$} & Alšovo nábřeží & 31 & 20,66 & $\mathbf{Y b}$ & Masarykovo nábřeží & 16 & 10,66 \\
\hline & other places & 33 & 22 & & other places & 42 & 27,33 \\
\hline
\end{tabular}




\begin{tabular}{|c|c|c|c|c|c|c|c|}
\hline \multicolumn{4}{|c|}{ POSITIVELY perceived segment of Santa Cruz } & \multicolumn{4}{|c|}{ NEGATIVELY perceived segment of Santa Cruz } \\
\hline Xc & $\begin{array}{l}\text { around Auditorio } \\
\text { de Tenerife }\end{array}$ & 97 & 64,66 & Yc & $\begin{array}{l}\text { around Avenida Ma- } \\
\text { rítima roundabout }\end{array}$ & 108 & 72 \\
\hline \multirow[t]{2}{*}{$X d$} & Plaza de España & 39 & 26 & Yd & $\begin{array}{l}\text { exit from Túnel Plaza } \\
\text { de España }\end{array}$ & 29 & 19,33 \\
\hline & other places & 14 & 9,33 & & other places & 13 & 8,66 \\
\hline
\end{tabular}

\subsubsection{Phase 1}

Fifty-seven percent of local inhabitants identified a segment of Rašínovo nábřeží (Xa) as a positively perceived part. A similar preference was noted in Santa Cruz, where nearly $65 \%$ of the local inhabitants identified the area near Auditorium de Tenerife $\left(X_{c}\right)$ as a positively perceived place (Table 1). At the same time this is a place where the lowest levels of noise were recorded out of the entire studied segment (Tables 2 and 3).

Compared to the good accessibility of the popular segment of waterfront in Prague, in Santa Cruz the respondents saw a problem in the site's position off the centre, which makes access more difficult (Tables 2 and 3 ). On the other hand, they positively perceive the representative character of the Auditorium, which had initially been criticised due to its purported elitist appearance [43].

Table 2. Evaluation of spheres of interest in positively and negatively perceived places within the segment of Prague

\begin{tabular}{|c|c|c|c|c|c|}
\hline \multicolumn{6}{|l|}{ RAŠÍNOVO NÁBŘEŽÍ (Xa) } \\
\hline positive aspects & no. of resp. & $\%$ & negative aspects & no. of resp. & $\%$ \\
\hline \multicolumn{6}{|l|}{ Economic sphere of interest } \\
\hline cultural events, bars & 56 & 37,33 & commercialization & 39 & 26 \\
\hline regular markets & 41 & 27,33 & exploitation of public space & 30 & 20 \\
\hline good accessibility & 27 & 18 & non-existent coordination & 23 & 15,33 \\
\hline \multicolumn{6}{|l|}{ Environmental sphere of interest } \\
\hline cooling effect on the city & 41 & 27,33 & water pollution & 62 & 41,33 \\
\hline habitat for aquatic wildlife & 26 & 17,33 & noise in the immediate vicinity & 39 & 26 \\
\hline \multicolumn{6}{|l|}{ Social sphere of interest } \\
\hline proximity of water's surface & 83 & 55,33 & pedestrians versus cyclists conflict & 62 & 41,33 \\
\hline genius loci of Prague & 28 & 18,66 & boat mooring - visual barrier & 24 & 16 \\
\hline \multicolumn{6}{|c|}{ AROUND KŘÍŽOVNICKÉ NÁMĚSTÍ (Ya) } \\
\hline \multicolumn{6}{|l|}{ Economic sphere of interest } \\
\hline \multirow[t]{2}{*}{ good accessibility from city centre } & 53 & 35,33 & high tourist commercialization & 78 & 52 \\
\hline & & & absence of Czech products on offer & 34 & 22,66 \\
\hline \multicolumn{6}{|l|}{ Environmental sphere of interest } \\
\hline & & & excessive traffic load & 97 & 64,66 \\
\hline & & & noise & 29 & 19,33 \\
\hline & & & waste accumulation & 11 & 7,33 \\
\hline \multicolumn{6}{|l|}{ Social sphere of interest } \\
\hline historical value of the place & 33 & 22 & homelessness, begging & 82 & 54,66 \\
\hline environment of original archit. & 28 & 18,66 & crime - pickpockets, sale of narcotics & 49 & 32,66 \\
\hline
\end{tabular}

Table 3. Evaluation of spheres of interest in positively and negatively perceived places within the segment of Prague

\begin{tabular}{|c|c|c|c|c|c|}
\hline \multicolumn{6}{|l|}{ AROUND AUDITORIO DE TENERIFE (Xc) } \\
\hline positive aspects & no. of resp. & $\%$ & negative aspects & no. of resp. & $\%$ \\
\hline \multicolumn{6}{|l|}{ Economic sphere of interest } \\
\hline representative character of the Auditorio & 57 & 38 & distance from city centre & 58 & 38,66 \\
\hline \multirow[t]{2}{*}{ good place for meetings } & 39 & 26 & monotony of space & 26 & 17,33 \\
\hline & & & low number of cultural events & 22 & 14,66 \\
\hline \multicolumn{6}{|l|}{ Environmental sphere of interest } \\
\hline better sensory quality of air & 48 & 32 & lack of greenery & 61 & 40,66 \\
\hline
\end{tabular}




\begin{tabular}{|c|c|c|c|c|c|}
\hline & & & $\begin{array}{l}\text { traffic noise } \\
\text { open space - severe weather effects }\end{array}$ & $\begin{array}{l}43 \\
28\end{array}$ & $\begin{array}{l}28,66 \\
18,66\end{array}$ \\
\hline \multicolumn{6}{|l|}{ Social sphere of interest } \\
\hline immediate proximity of water's level & 64 & 42,66 & ship/tanker mooring - visual barrier & 48 & 32 \\
\hline impact of the dominant landmark's size & 29 & 19,33 & monotony of street furniture & 37 & 24,66 \\
\hline \multicolumn{6}{|c|}{ AROUND AVENIDA MARÍTIMA ROUNDABOUT (Yc) } \\
\hline \multicolumn{6}{|l|}{ Economic sphere of interest } \\
\hline \multirow[t]{2}{*}{ good accessibility from city centre } & 38 & 25,33 & undefined segmentation of space & 81 & 54 \\
\hline & & & lack of clarity, bike lane & 23 & 15,33 \\
\hline \multicolumn{6}{|l|}{ Environmental sphere of interest } \\
\hline \multirow[t]{3}{*}{ proximity of Barranco de Santos } & 17 & 11,33 & noise & 63 & 42 \\
\hline & & & excessive traffic load & 59 & 39,33 \\
\hline & & & absence of greenery & 14 & 9,33 \\
\hline \multicolumn{6}{|l|}{ Social sphere of interest } \\
\hline \multirow[t]{2}{*}{ outdoor gym features, skate park } & 77 & 51,33 & visual barriers, tankers & 78 & 24 \\
\hline & & & pedestrians versus cyclists conflict & 36 & 52 \\
\hline
\end{tabular}

\subsubsection{Phase 2}

This phase of research introduced an overview of the perception of social and physical aspects with a positive impact on the users of waterfronts in both cities (Graph 1). In both locations, $84 \%$ of respondents referred to the essential importance of close contact with the water's surface (D) among all the social aspects perceived. In Prague, the popularity of this poetic aspect of the place was mentioned mostly by those in the senior citizens' category, while in Santa Cruz it was by people in productive age, mainly due to the greater distance of the site from the city centre. A general consensus in the perception of waterfronts is evident also in the importance of another social aspect - the design and appearance of the place (E).

Among physical aspects, the clarity and legibility of the space (J) was positively perceived in both cities. The responses of the users confirm the theory of Jastrzab [59], who states that there are several reasons why the role of clarity and legibility is important in the composition of public spaces: 1. orientation in the space; 2 . emotional perception; 3 . educational and moral aspects. On the other hand, negatively perceived physical aspects in Prague were those of lack of greenery and street furniture (I). Absence of greenery is perceived predominantly by visual means, in the summer months also through the climate as the surfaces tend to overheat and there is no shade. Residents in Santa Cruz referred to the lack of user amenities (K). 


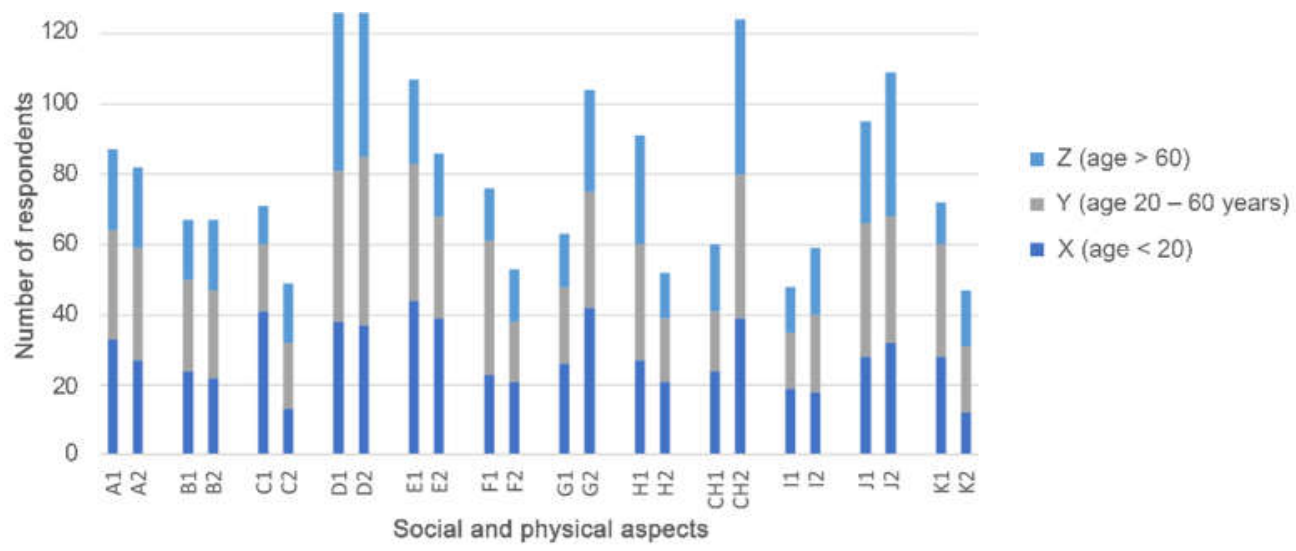

Social aspects (\% of presence for the users)

A user-friendliness $(58 \% / 54,6 \%)$

B accessibility and inclusiveness $(44,6 \% / 44,6 \%)$

C cultural events taking place $(54 \% / 32,6 \%)$

D proximity of water's surface $(85,3 \% / 84,6 \%$ )

E design and appearance of the place $(71,3 \% / 57,3 \%)$

F sports activities $(50,6 \% / 35,3 \%)$

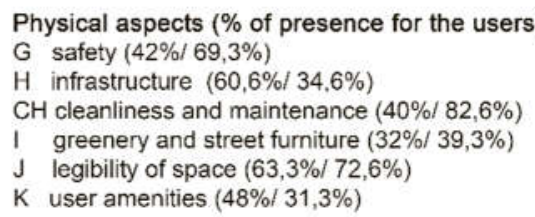

Graph 1. Importance of social and physical aspects in the positively perceived segment of Prague $(\mathrm{A} 1, \mathrm{~B} 1, \ldots)$ and Santa Cruz de Tenerife (A2, B2, ...)

\subsubsection{Phase 3}

The resulting graphs indicate the daytime rhythm of people passing through the positively and negatively perceived segment in Prague (Graph 2) and in Santa Cruz (Graph 3). The results for both the cities show that the negatively perceived landmarks demonstrate a higher constancy of pedestrian users. Compared to the busiest hour of the day, only $54 \%$ of local pedestrian users pass through the area around Křížovnické náměstí in Prague (Ya) in the least busy time of day. The maximum deviation in the number of passers-by (dynamics of movement) in Santa Cruz (Yc) is $46 \%$. More variable dynamics of movement was recorded in the positively perceived segments. In Prague (Xa) the maximum deviation was $25 \%$, in Santa Cruz ( $\left.X_{c}\right)$ it was $22 \%$. In this case the sites are visited purposefully as the final destination of the residents' presence there.

The positively perceived segments are also those that, in both the studied cities, are situated closer to the water (Figure 1). According to the air temperature measurements (Graphs 2 and 3 ) in these segments ( $X_{a}$ and $X_{c}$ ) the daytime temperature maximum came earlier than in the segments situated farther from the water's surface (Ya and Yc).

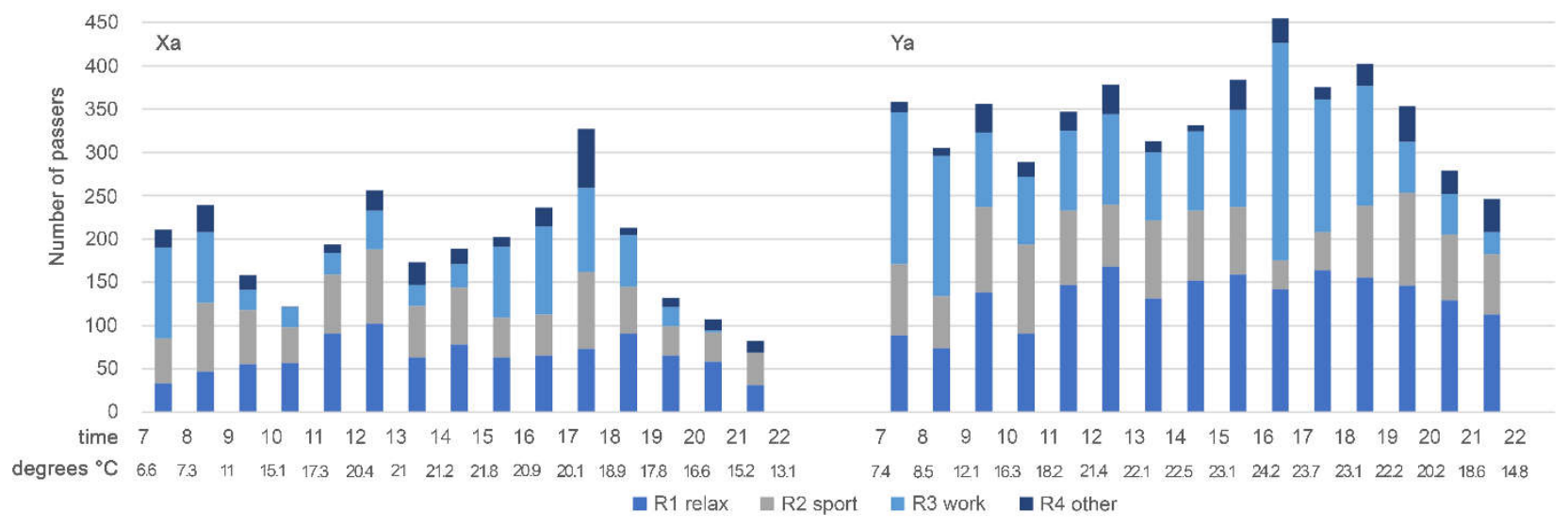

Graph 2. Daily rhythm of passers in the positively (Xa) and negatively (Ya) perceived segment of Prague 


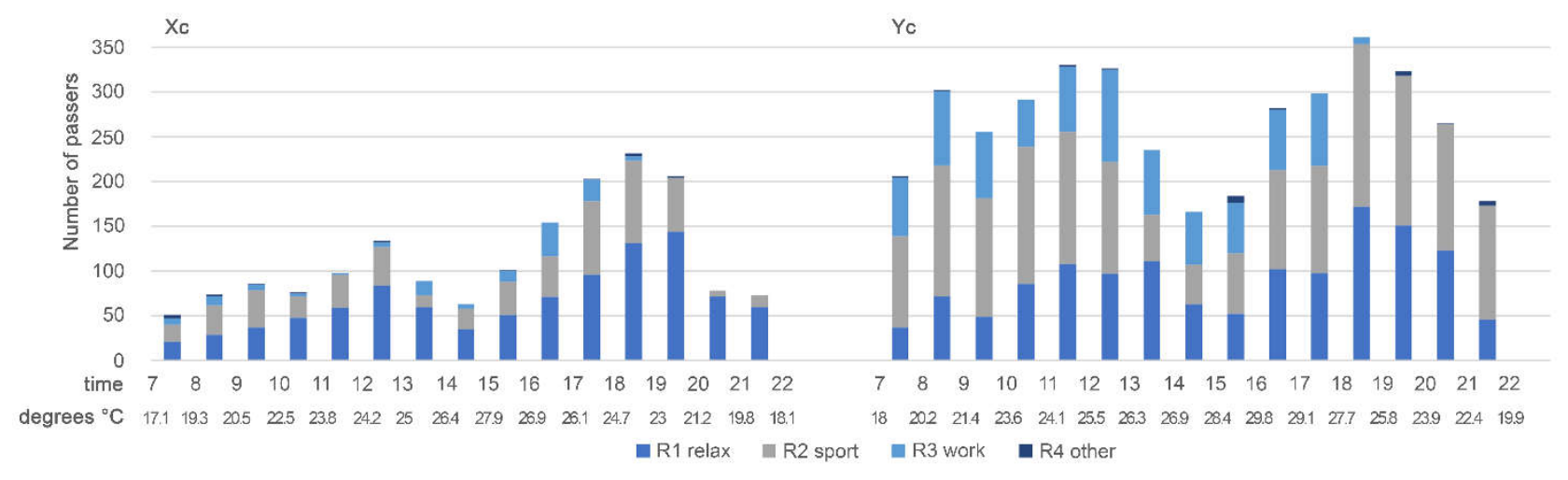

Graph 3. Daily rhythm of passers in the positively $\left(X_{c}\right)$ and negatively $\left(Y_{c}\right)$ perceived segment of Santa Cruz

\section{Discussion}

Maximisation of the positive impact of the waterfront space for mental recreation of its users can be achieved by evoking harmony through a combination of the psychological and climatic effects of the environment. These elementary components have been essential mainly in recent years, when, according to Kennedy and Adolphs [44], the stress of urban residents has increased. In both the studied cases the results showed that water's surface is a key element in the perception of the studied space. The measured air temperatures point to the importance of the aquatic environment for the cooling of urban areas and therefore to its contribution to the mental health of the residents.

\subsection{Historical changes of the potential of waterfronts to the users}

The approach to the development of the waterfronts differs in each of the cities due to the different character of the places and the needs of local residents. The maritime region had a harder task due to the historically higher importance of shipping for the supply and sustenance of the island. In Santa Cruz the major construction boom came after 1706 when the city's port became the main port on the island. Due to this, the functional layout of the waterfront still feels rather complicated and lacks clarity for users. The development of river waterfronts in Central Europe was somewhat less turbulent. Prague has a longer history of its promenade along the river, which dates back to the second half of the $19^{\text {th }}$ century. In terms of a higher population in cities, the need for recreation and mental regeneration was increasing.

Both cities currently face increased pressure from urbanisation. As González and Quesada [45], state, the problem lies in the abandoning of the traditional concepts of a city in terms of the recent development of the waterfront in Santa Cruz, or as Szentesiová [46] states, in the pressure of developing a commercial environment that introduces many aspects jeopardising the values in the central parts of Prague. Metropolises are currently managed by means of functional planning policies that take into account the potential of waterfronts. The positively perceived reconstructions of Plaza de España in Santa Cruz and Rašínovo nábřeží in Prague, referred to in the study, are examples of such functional policies. Based on the results it is possible to agree with Gunay and Dokmeci [33] that regeneration of waterfronts occurs at the problematic and controversial interface between a port's function and the broader urban environment.

\subsection{Proximity of water and the choice of segments of waterfronts}

The proximity of water affects the choice of the segments of waterfronts preferred by the users. However, the results revealed that from a psychological point of view, the possibility of a direct unblocked view of the water's surface makes a waterfront more effective than the actual proximity to the water. Upon these findings, the Mental leaning out over theory of Moore and Lidz [36] can be extended as follows: emotional contact with water occurs when people are allowed to get as close as possible, without actually touching the element, or when visual contact is made possible. The environmental sphere of interest in 
Phase I of the research highlighted the problem of traffic noise, its perception, and its high levels in all the studied urban environments. This confirms the results of den Boer and Schorten [47], who, in the conclusion to the report commissioned by the European Federation for Transport and Environment (T\&E), stated that traffic noise must be taken as seriously as other forms of pollution, because it has a similar detrimental effect on human health and psyche. The results at the same time confirmed the theory of Timur [48] that aquatic environments within urban spaces act as the best barriers blocking artificial noises.

\subsection{Comparison to other social aspects}

Through the research into social aspects in Phase II the theory of the preference of perception of the water element for the overall regeneration of individuals in each of the metropolises has been confirmed against the other aspects. The presence of a natural element is therefore more important for the users than the physical appearance of the place and its architectural design. It is necessary to consider the fact that the overall population density of Prague is 2,700 inhabitants $/ \mathrm{km}^{2}$ while in Santa Cruz de Tenerife it is only 1,500 inhabitants $/ \mathrm{km}^{2}$. The results in the social aspects of Prague have pointed to the increasing sensitivity to perceiving the aquatic element with the users' age compared to Santa Cruz, where the water's surface was perceived mostly by the productive age group. These numerical results confirm the hypothesis that the need for mental hygiene and preference of aquatic environments in cities increases with the age of individuals, predominantly in cities with denser populations. The emphasis on the impact of the environment on one's personality is expressed also in the concept of Lewin [49], according to whom the development of one's personality is in fact the development of the way we perceive the environment.

A high degree of preference of the restorative effect of the water element in urban planning solutions is highlighted also by the differences between the values of the dynamics of movement (difference in the number of passers in time with the maximum traffic compared to the time with minimum traffic) of individuals in the positively perceived segments compared to the negatively perceived ones. The negatively perceived segments of cities are under consistent load, with the maximum digression from the $50 \%$ average in both cities. Among the places positively perceived by the users the maximum difference in daily attendance is $23 \%$. It is apparent that the segments preferred by the users on the island and in the Central European metropolis are visited intentionally as a destination of their trip seeking regeneration.

\subsection{Differences in the perception of daily temperatures}

In Phase III of the Results (Graphs 2 and 3) respondents at the waterfront, especially those from Santa Cruz de Tenerife, rated their perception of high temperatures. Pedestrians use the the waterfront outside the hottest hours of the day, which is determined by the local subtropical climate with higher temperatures. Positive perception of the waterfront cooled by water was observed in both the studied cities, also through the air temperatures actually measured which were lower than in the built-up areas. This effect is caused mainly by the high thermal capacity of water, which acts by constantly slowing down the rate of heating-up of the surface during the day [50]. Built-up areas and surfaces prone to overheating retain heat longer. This effect is apparent in both case studies, in later hours of the thermal maximum of the day measured in built-up areas compared to the parts of waterfront in direct contact with the water's surface. In general, preference of places in terms of time depends on the thermal situation of the city/waterfront and on a convenient spatial composition covering sufficient shade and greenery.

According to many indicators, the Earth's climate is changing. The main manifestation of this climate change is global warming [51]. Negative impacts of extreme weather are becoming more and more intensive, especially in urban areas [52]. As the study has shown, an essential problem of urbanisation is the expansion of unnatural surfaces that absorb and retain heat at the expense of natural surfaces (greenery and water). According to Chudnovsky et al. [53] it is unnatural surfaces that negatively affect radiation, thermal and moisture conditions. In both the studied cases we observed the phenomenon of the 
greater share of man-made surfaces conditions higher temperatures in built-up areas of cities compared to temperatures in areas with a higher percentage of greenery. This phenomenon is known as the Urban Heat Island, UHI [54]. The results of the study as well as literature sources deny the existence of global cooling, which has been repeatedly rejected as a 1970s scientific myth [55]. In recent years, global warming has increasingly been perceived directly by the public. In Santa Cruz, the effect of the city heating up is perceived by $51 \%$ of respondents, in Prague it is $44 \%$. The results are also confirmed by the study of Akerlof et al. [56].

\section{Conclusions}

Based on the results it can be stated that waterfronts in both cities in the case study are perceived by their users as parts of the urbanised area that are essential for recreation. As Bergen et al. [57], Arriaza et al. [60], and Acar et Sakici [58] point out, the presence of water determines a positive perception of landscape and cityscape. The overall importance of the water's surface from a psychological perspective is higher in the environment of Prague compared to Santa Cruz de Tenerife. One of the direct reasons for this could be the higher percentage of the waterfront allowing for visual contact with water, but also the higher population density with which the need for contact with natural elements increases. The results suggest that besides the presence of the water's surface and a convenient composition and design, psychological perception of waterfront users is directly affected by the presence of UHI.

Preferences for individual parts of waterfronts indicate to a high degree of residents' perception of air temperatures. The waterfront as an urban space has a positive impact on mental aspects, but mainly on human health. The results of this study appeal to the observance of ecosystem-based approaches to adaptation, which may maintain and support the cooling effect of waterfronts in cities. In future projects it is therefore highly desirable to reflect the need for greenery in streets and on roofs, as well as for the construction of pavements and roads from water-permeable materials, and to ensure better light reflectance of the materials used for pedestrian surfaces. Convenient design and composition solutions ensuring optimal air flow are also of major importance - the inflow of cool air and the outflow of warm air. The study has also shown the importance of shading playgrounds, sports pitches, and public spaces in general, as well as considerate water management. Adaptation to the ongoing and expected impacts of climate change and the effort to eliminate them are essential for the sustainable development of cities.

This study was carried out as an experiment studying the reactions of users to the presence and importance of waterfronts in terms of urban environment. The results of the studies indicate awareness of the importance of these spaces, as well as the real threat of overheating of urban areas. Users adapt their behaviour to the temperatures they perceive. Our study results could be used to better integrate psychological effects caused by water in planning future waterfront sites. The study should be the basis for spatial planning and individual emerging projects. The results were processed according to the above methodology. The methodology is applicable to any other localities in the future.

For the future of modern and balanced urban planning it is necessary to take into account the functional arrangement of waterfront spaces to offer residents and users the desired restorative effect regarding sustainability. And water offers great potential for urban planning to enhance the restorative psychological effects of public spaces and ensure sustainability.

\section{Patents}

Conflicts of Interest: The authors declare no conflict of interest.

Funding: This research received no external funding.

Data Availability Statement: Not applicable.

Institutional Review Board Statement: Not applicable.

Informed Consent Statement: Not applicable. 


\section{References}

1. Carr, S.; Francis, M.; Rivlin L.G.; Stone A.M. Public Space; Cabrdige University Press: New York, NY, USA, 1992.

2. Graham, S.; Parkinson, C.; Chahine, M. The Water Cycle, NASA Earth Obs, Greenbelt, Md. Accessed 1.10.2010. Date of access: 1.10.2010. Available at https://earthobservatory.nasa.gov/features/Water

3. Önen, M. Examinatıon Rivers' Recreational Potantial As An Urban Coastal Space: Case Study, Eskişehır Porsuk Creek and İstanbul Kurbağalıdere. Master thesis, Istanbul Technical University, Institute of Science And Technology, Istanbul, 2007. Available at: http://hdl.handle.net/11527/3675

4. Booth, N. K. Basic Elements of Landscape Architectural Design; Waveland Press, Inc.: Chicago, Illinois, USA, 1989.

5. Herzog, T. R. A Cognitive Analysis of Preference for Waterscapes. Journal of Environmental Psychology 1985, 5, 225-241. DOI: http://dx.doi.org/10.1016/S0272-4944(85)80024-4

6. Bulut, Z.;Yilmaz, H. Determination of waterscape beauties through visualquality assessment method, Environmental Monitoring and Assessment 2008, 154, 459-468. DOI: https://doi.org/10.1007/s10661-008-0412-5

7. Ebbensgaard, C.L. 'I like the sound of falling water, it's calming': engineering sensory experiences through landscape architecture. Cultural Geographies 2017, 24 (3), 441-455. DOI: https://doi.org/10.1177/1474474017698719

8. Kahn, D. Noise, Water, Meat: A History of Sound in the Arts; Mit Press: Boston, Massachusetts, USA, 1999.

9. Hattapoğlu, M. Z. Place of Water Phenomenan in Evoluation of Settlements and Teinterpretation of it as an Urban Design Element. Diploma thesis, Mimar Sinan Arts of University, Institute of Science And Technology, Istanbul, 2004.

10. Bachelard, G. Water and dreams: An essay on the imagination of matter; Pegasus Foundation: Dallas, Texas, USA, 1983.

11. Kaplan, S. and Kaplan, R. The experience of nature: a psychological perspective; Cambridge University Press: New York, NY, USA, 1989.

12. Krajhanzl, J. Psychology of Relationship toward Nature and the Environment; Lipka, MUNI press: Brno, Czech Republic, 2014.

13. Krajhanzl, J. Description of personal relationship towards nature: introduction to theory and terminology, Diploma thesis, Charles University, Faculty of arts and philosophy, Prague, 2010a.

14. Chenoweth, R. E.; Gobster, P. H. The nature and ecology of aesthetic experiences in the landscape. Landscape journal 1990, 9 (1), 1-8. Available at: https://www.jstor.org/stable/43322886?seq=1

15. Krajhanzl, J. Environmental and Pro-environmental Behavior. School and Health 2010b, 21, 251-274. Available at: https://www.researchgate.net/publication/265508352_Environmental_and_Pro-environmental_Behavior

16. Compton, M. Living Water: Exploring Psychological Aspects of our Attraction and Connection to an Element in Nature. Master thesis, Institute of Transpersonal Psychology, Palo Alto, California, 2003. Available at: https://search.proquest.com/openview/4da9a496badeee5d6d62b51f70a66c62/1?pq-origsite=gscholar\&cbl=18750\&diss=y

17. Gifford, R. Environmental Psychology Matters. Annual Review of Psychology 2013, 65 (1), 541-579. DOI: https://doi.org/10.1146/annurev-psych-010213-115048

19. Velarde, M. D.; Fry, G.; Tveit, M. Health effects of viewing landscapes - Landscape types in environmental psychology. Urban Forestry E Urban Greening 2007, 6 (4), 199-212. DOI: https://doi.org/10.1016/j.ufug.2007.07.001

Gailing, L.; Leibenath, M. The Social Construction of Landscapes: Two Theoretical Lenses and Their Empirical Applications. Landscape Research 2015, 40 (2), 123-138. DOI: https://doi.org/10.1080/01426397.2013.775233

20. Mayer, F. S.; Mcpherson Frantz, C.; Bruehlman-Senecal, E.; Doliver, K. Why is nature beneficial?: The role of connectedness of nature. Environment and Behavior 2009, 41 (5), 607-643. DOI: https://doi.org/10.1177/0013916508319745

21. Kumar, J.; Muntner, P.; Kaskel, F. J.; Hailpern, S. M.; Melamed, M. L. Prevalence and Associations of 25-Hydroxyvitamin D Deficiency in US Children: NHANES 2001-2004. Pediatrics 2009, 124 (3), 362-370. DOI: https://doi.org/10.1542/peds.2009-0051 Ulrich, R. S. Aesthetic and Affective Response to Natural Environment. In: Altman I., Wohlwill J.F. (eds) Behavior and the Natural Environment 1983. Human Behavior and Environment (Advances in Theory and Research), Vol. 6, 85-125. DOI: https://doi.org/10.1007/978-1-4613-3539-9_4

23. Roszak, T. The Voice of the Earth: An Exploration of Ecopsychology; New York: Simon \& Schuster: New York, NY, USA, 1992.

24. Moretti, M. Cities on Water and Waterfront Regeneration: The Role of Culture and Events. Grundtvig, III. Meeting Rivers of Change-River//Cities. Wien, Austria, September 5th-7th 2008. Date of access: 10.05.2012. Available at: http://www.rivercities.nazwa.pl/www/download/m.moretti_vienna2008.pdf

25. Hradilová, I. Influence of urban waterfront appearance on public space functions. Acta Universitatis Agriculturae et Silviculturae Mendelianae Brunesis 2012, 60 (8), 261-268. DOI: https://doi.org/10.11118/actaun201260080261

26. Hou, J. Hybrid landscapes: toward an inclusive ecological urbanism on Seattle's Central Waterfront. In: ACSA 94th annual konference, Getting real: design ethos now. Salt Lake City, Utah. March 30th to April 3rd 2006 (p. 245-250). Available at: https://www.acsa-arch.org/chapter/hybrid-landscapes-toward-an-inclusive-ecological-urbanism-on-seattles-central-waterfront/ Wrenn, D. M., Cassazza, J. A., Smart, J. E. Urban waterfront development; Urban Land Institute: Washington, D.C., USA, 1983. Al Ansari; F. Public open space on the transforming urban waterfronts of Bahrain: the case of Manama City. Doctoral thesis, Newcastle University, Newcastle upon Tyne, 2009. Available at: https://pdfs.semanticscholar.org/9ad6/a7f2ce9b16b1b23b858abd07c844b50f2702.pdf 
29. Miller, L.M. Sustainable Waterfront Revitalization: Baltimore, San Francisco, and Seattle. Master tesis, California Polytechnic State University, San Luis Obispo, 2011. DOI: https://doi.org/10.15368/theses.2011.121

30. World Commission on Environment and Development. Report of the World Commission on Environment and Development: Our Common Future, Oxford: Oxford University Press. Date of Access: 10.2.1987. Available at: http://www.askforce.org/web/Sustainability/Brundtland-Our-Common-Future-1987-2008.pdf

31. Romein, A. Leisure in waterfront redevelopment: an issue of urban planning in Rotterdam? In: AESOP Conference, The Dream of a GREATER Europe. Wien, Austria, 2005. Available at: http://citeseerx.ist.psu.edu/viewdoc/download?doi=10.1.1.548.5376\&rep=rep1\&type=pdf

32. Jensen, C.R. and Guthrie S. Outdoor recreation in America; Human Kinetics: Champaign, IL, USA, 2006.

33. Gunay, Z.;Dokmeci, V. Culture-led regeneration of Istanbul waterfront: Golden Horn Cultural Valley Project. Cities 2012, 29 (4), 213-222. DOI: https://doi.org/10.1016/j.cities.2011.08.010

34. Kostopoulou, S. On the Revitalized Waterfront: Creative Milieu for Creative Tourism. Sustainability 2013, 5 (11), $4578-4593$. DOI: https://doi.org/10.3390/su5114578

35. Breen, A. and Rigby, D. The New Waterfront: A Worldwide Urban Success Story; McGraw-Hill: New York, NY, USA, 1996.

36. Moore, C. W. and Lidz, J. Water and Architecture; Harry N. Abrams: London, Great Britain, 1994.

37. Omar, N. A.; Saeed, E. H. An Integrated Strategy for Waterfront Redevelopment Case Study: Alexandria, Egypt. Engineering Research Journal 2019, 2, 93-109. DOI: https://doi.org/10.21608/erjeng.2019.125516

38. Kučera, P. Pražské náplavky Website, Date of access: 18.8.2016. Available at: https://prazskenaplavky.cz/historie

39. Stehlík, F. and Žáček, F. Stehlíkưv historický a orientační průvodce ulicemi hlavního města Prahy; Stehlík: Prague, Czech Republic, 1929.

40. Luis, M. J. Y. and Sanchez, J. M. H. La historia de santa Cruz de Tenerife; Ayuntamiento de Santa Cruz de Tenerife: Santa Cruz de Tenerife, Spain, 1995.

41. Alvarez, M. A.; Trapa, T. I. Auditorio de Tenerife. Informes de la Construcción 1998, 50 (455), 41-52. DOI: https://doi.org/10.3989/ic.1998.v50.i255.902

42. Herzog \& de Meuron Team. Herzog \& de Meuron Website, 2008. Available at: https://www.herzogdemeuron.com/index/projects/complete-works/176-200/182-plaza-de-espana.html .Accessed 7.2.2017

43. Rivero, J. L. Auditorio de Tenerife. Visiones Vision, Tenerife, Date of access: 16.11.2013. Available at: https://www.redescena.net/descargas/proyectos/tenerife.pdf

44. Kennedy, D. P.; Adolphs, R. Stress and the city. Nature 2011, 474 (7352), 452-453. DOI: https://doi.org/10.1038/474452a

45. González Chávez, C., M.; Quesada Acosta, A., M. El nuevo litoral de Santa Cruz de Tenerife y las Palmas de Gran Canaria. Hitos arquitectónicos y urbanísticos. Coloquios de Historia Canario Americana 2004, 16, 1106-1124. Availeble at: https://mdc.ulpgc.es/utils/getfile/collection/coloquios/id/1813/filename/1820.pdf

46. Szentesiová, K. Urbanistický vývoj Prahy za posledních 20 let [The urban development of Prague in the last two decades]. Urbanismus a Územní Rozvoj 2010, 5 (8), 129-147. Available at: https://www.uur.cz/images/5-publikacni-cinnost-a-knihovna/casopis/2010/2010-05/15_urbanisticky.pdf

47. den Boer, L. \& Schroten, A. Traffic noise reduction in Europe. Report of CE Delft, Commissioned by the European Federation for Transport and Environment (T\&E), Brussels, 2007.

48. Timur, U. P. Urban Waterfront Regenerations. Advances in Landscape Architecture 2013, chapter 7, 169-205. DOI: https://doi.org/10.5772/55759

49. Lewin, K. Field Theory of Social Science: Selected Theoretical Papers; Harper \& Row: New York, NY, USA, 1951.

50. U. S. Envirnmental protection agency. Reducing urban heat islands: Compendium of strategies. Date of access: 20.4.2019. Available at: https://www.epa.gov/heatislands/heat-island-compendium

51. IPCC. Climate Change 2013: The Physical Science Basis. Contribution of Working Group I to the Fifth Assessment Report of the Intergovernmental Panel on Climate Change. Cambridge University Press, Cambridge, United Kingdom and New York, USA, 1535 pp.

52. Satterthwaite, D. Adapting to Climate Change in Urban Areas: The Possibilities and Constraints in Low-and Middle-income Nations. IIED, London, 2007.

53. Chudnovsky, A., Bendor, E. \& Saaroni, H. Diurnal thermal behavior of selected urban objects using remote sensing measurements. Energy and Buildings 2004, 36 (11), 1063-1074. DOI: https://doi.org/10.1016/j.enbuild.2004.01.052

54. Balchin, W. G. V.; Pye, N. A micro-climatological investigation of Bath and the surrounding district. Quarterly Journal of the Royal Meteorological Society 1947, 73 (317-318), 297-323. DOI: https://doi.org/10.1002/qj.49707331706

55. Peterson, T. C.; Connollay, W. M.; Fleck, J. The myth of the 1970s global cooling scientific consensus. Bulletin of the American Meteorological Society 2008, 89 (9), 1325-1337. https://doi.org/10.1175/2008BAMS2370.1

56. Akerlof, K.; Maibach, E. W.; Fitzgerald, D.; Cedeno, A. Y.; Neuman, A. Do people "personally experience" global warming, and if so how, and does it matter?. Global environmental change 2013, 23 (1), 81-91. DOI: https://doi.org/10.1016/j.gloenvcha.2012.07.006

57. Bergen, S. D.; Ulbricht, C. A.; Fridley, J. L.; Ganter M. A. The validity of computer generated graphic images of forest landscapes. Journal of Environmental Psychology 1995, 15 (2), 135-146. DOI: https://doi.org/10.1016/0272-4944(95)90021-7 
58. Acar, C.; Sakıcı, Ç. Assessing landscape perception of urban rocky habitats. Building and Environment 2008, 43 (6), 1153-1170. DOI: https://doi.org/10.1016/j.buildenv.2006.02.026

59. Jastrząb, T. Przestrzenie publiczne we wspótczesnej urbanistyce i architekturze; Wydawnictwo Politechniki Poznańskiej: Poznań, Poland, 2004.

60. Arriaza, M.; Canas-Ortega, J. F.; Canas-Madueno, J. A.; Ruiz-Aviles, P. Assessing the visual quality of rural landscapes. Landscape and Urban Planning 2004, 69, 115-125. 